\title{
A simple protein extraction method for proteomic analysis of mahogany (Swietenia macrophylla) embryos
}

\author{
Noraliza Alias ${ }^{*}$, Wan Mohd Aizat ${ }^{2}$, Nor Datiakma Mat Amin ${ }^{3}$, Norwati Muhammad ${ }^{1}$ and Normah \\ Mohd Noor ${ }^{2}$
}

\author{
${ }^{1}$ Forestry Biotechnology Division, Forest Research Institute Malaysia (FRIM), 52109 Kepong, Selangor, \\ Malaysia \\ ${ }^{2}$ Institute of Systems Biology, Universiti Kebangsaan Malaysia, 43600 UKM Bangi, Selangor, Malaysia \\ ${ }^{3}$ Natural Product Division, Forest Research Institute Malaysia (FRIM), 52109 Kepong, Selangor, Malaysia
}

*Corresponding author: noraliza@ frim.gov.my

\begin{abstract}
In any proteomic studies, protein extraction and sample preparation are the most crucial steps for obtaining optimal results. This is to ensure extracted proteins are not only high in yield but also clean from contaminants that could affect downstream proteomic applications such as two dimensional gel electrophoresis (2-DE) and mass spectrometry. Tissues from plants and trees such as Swietenia macrophylla are often rich in non-protein contaminating substances, which could interfere in the proteomic applications. S. macrophylla or also known as the mahogany is one of the most valuable tree species in the world. Studies on proteins for this tree as well as its seeds are very limited. We have extracted proteins from S. macrophylla seeds (specifically embryo tissues) using three different methods, each having different lysis buffer recipes. Furthermore, another set of samples were precipitated using trichloroacetic acid/acetone prior to the three extraction methods to further purify the protein samples. The results from 2-DE analysis showed approximately 240 protein spots were detected from the successful protocol using a lysis buffer of $9 \mathrm{M}$ urea, $4 \%$ CHAPS, $0.5 \%$ triton X-100 and $100 \mathrm{mM}$ DTT without TCA/acetone precipitation. This study highlights the aspects of sample preparation for S. macrophylla embryos, focusing on the total protein extraction and resolution in SDS-PAGE as well as 2-DE. Furthermore, this is the very first report of the proteome 2DE profile from S. macrophylla embryo.
\end{abstract}

Keywords: embryo, seeds, proteomic, two-dimensional gel electrophoresis, Mahogany

Abbreviations: 2-DE_two dimensional gel electrophoresis; IEF_isoelectric focusing; IPG_immobilised pH gradient; TCA_trichloro acetic acid

\section{Introduction}

Swietenia macrophylla, locally known as mahogany is among the world most important and expensive timbers. It is categorized as a medium hard wood tree which its market value could reach more than USD100 million per year (CITES, 2002). Excessive logging for this species due to its high demand and competitive market leads to its dwindling population and hence severely threatened. Therefore, in order to protect this species, S. macrophylla has been listed in the Appendix II of the Convention on International Trade in Endangered Species (CITES) which legislate an export permit for any shipments of this timber . The exporters, importers and users of mahogany products are now responsible for obtaining the timber legally to ensure that the regulation is met and the sustainability of $S$. macrophylla can be safeguarded in the long run. Furthermore, the forest plantation of S. macrophylla is another strategy to increase the supply of this precious timber to the industry. As such, the supply of quality planting material such as seeds is crucial to ensure the success of the plantation program.

Seeds provide the main source of breeding and planting materials (Krisnawati et al., 2011). Seed storage under low temperature and humidity conditions have been widely recognized to delay seed aging, but it is costly and only partially prevents seed deterioration (Ellis et al., 1992). Therefore, it is important to study seed aging and deterioration to better preserve seeds such as $S$. macrophylla. Various molecular and structural changes can be caused by seed deterioration including DNA and RNA degradation, fatty acid oxidation, losses in membrane integrity, defects in protein synthesis, as well as the increase of reactive oxygen species (ROS) and chaperones (El-MaaroufBouteau and Bailly, 2008). Thus, it is important to identify the molecular and biochemical regulation related to seed storability, particularly using high throughput techniques such as proteomics. 
Proteomics involves a large-scale study of complex mixtures of proteins called proteome. Compared to genomics which mostly study the fixed sequences of ones genome, proteome is highly diversified due to post-translational modifications (PTM) on proteins and may be modified in response to various developmental stages, treatments and environmental stresses (Amme et al., 2006). Proteomics applications are also vast and can be used to analyze functional aspects of proteins such as protein-protein interactions, activities and structures (Canovas et al., 2004). Furthermore, proteomics can also be used to investigate the expression of total proteins in any samples, by performing techniques such as two-dimensional gel electrophoresis (2-DE). One of the advantages of proteomics research via $2-\mathrm{DE}$ is the ability to simultaneously scrutinize and compare the expression of hundreds of proteins from any given samples. This could generate a catalogue of protein profiles in any organisms of interest including $S$. macrophylla, particularly pertaining to its seeds' preservation and molecular regulation.

The aim of our study is to develop a method for the 2-DE analysis of $S$. macrophylla embryo proteins, which will allow visualization of a maximum of total proteins from the sample. Preparation of high-quality protein samples from plants has been problematic using various protein extraction protocols due to high salts, polysaccharides, lipids and proteases (Gorg et al., 2004; Carpentier et al., 2005). In this study, we have compared three different protocols, each having different lysis buffers to measure their protein extraction yield from the $S$. macrophylla embryo. Furthermore, a different set of experiment using trichloroacetic acid (TCA)/acetone precipitation prior to the three lysis buffer extraction steps was done to further purify the protein samples. These different protocols are evaluated based on their protein yield, SDS-PAGE band intensity as well as the number of protein spots on 2-DE.

\section{Results and Discussion}

Most studies in the method development of 2-DE profiling were comparing different protocols such as using TCA/acetone, phenol or methanol precipitation (Nandakumar et al., 2003; Carpentier et al., 2005; Wang et al., 2006; Maldonado et al., 2008). One of the studies in the method development of protein extraction from plants was carried out using TCA/acetone method (Wang et al., 2004). This method was also employed by Saravanan and Rose (2004) which noticed missing proteins, possibly due to protein solubility issues. The TCA/acetone precipitation step is thought to minimize protein degradation and proteases activity as well as reducing contaminants such as salts or polyphenols (Shaw and Riederer, 2003). However, the protein extracted by this TCA/acetone method is often difficult to be dissolved in lysis buffer solution
(Carpentier et al., 2005). In this study, protocols with and without TCA/acetone precipitation followed by three different lysis extraction buffers were examined to obtain the best protein yield.

\section{Protein extraction without TCA/acetone precipitation produced higher protein yield}

The total amount of proteins extracted from $S$. macrophylla embryos varied depending on the protocols used. Protein extraction protocols without TCA/acetone precipitation step produced relatively higher amount of protein concentration than the protocols with TCA/acetone precipitation (Table 1). Proteins extracted without TCA/acetone precipitation followed by extraction buffer L1 (7 M urea, $2 \mathrm{M}$ thiourea, $40 \mathrm{mM}$ tris, $75 \mathrm{mM}$ DTT and $4 \%$ CHAPS) produced $12.4 \pm 0.95 \mu \mathrm{g} / \mu \mathrm{L}$ protein concentration, while buffer L2 (8 M urea, $60 \mathrm{mM}$ DTT, 4\% CHAPS dan $2 \%$ pharmalyte $\mathrm{pH} 3-10)$ produced $12.9 \pm 0.83$ $\mu \mathrm{g} / \mu \mathrm{L}$ and buffer L3 (9 M urea, $100 \mathrm{mM}$ DTT, 4\% CHAPS and $0.5 \%$ triton $\mathrm{X}-100)$ produced $5.2 \pm 0.14$ $\mu \mathrm{g} / \mu \mathrm{L}$ (Table 1). Meanwhile, the protein yield extracted using TCA/acetone precipitation produced much lower yield, e.g. 3.0 $\pm 1.16 \mu \mathrm{g} / \mu \mathrm{L}$ for buffer $\mathrm{L} 1$ and $5.0 \pm 0.90 \mu \mathrm{g} / \mu \mathrm{L}$ for buffer L2. Buffer L3 on the other hand produced $5.0 \pm 1.21 \mu \mathrm{g} / \mu \mathrm{L}$, which is not significantly different compared to its respective TCA/acetone precipitation sample.

The separation of proteins was first performed using SDS-PAGE $(12.5 \%)$ followed by silver nitrate and coomassie brilliant blue staining methods. A total of 50 $\mu \mathrm{g}$ protein was loaded into each well of SDS-PAGE. Protein separation without TCA/acetone precipitation step showed higher intensity of protein bands compared to protocols with TCA/acetone precipitation step (Fig. 1). Furthermore, high molecular weight protein bands were almost disappeared for protein samples using the extra TCA/acetone precipitation step. The TCA/acetone step might cause protein degradation as argued by Wang et al. (2006) due to longer experimental time. In our case, the extra precipitation steps may result in possible protein modification and degradation after long exposure to the low $\mathrm{pH}$ buffer. This condition may also be the reason for the pellet insolubility in rehydration buffers, causing a low protein yield. Protein solubility is the key factor in ensuring the success of analyzing the protein separation in 2-DE (Valente et al., 2012). Therefore, precipitation with TCA/acetone is seemed unsuitable for $S$. macrophylla seed proteins.

Subsequently, based on the results obtained, the proteins from $S$. macrophylla embryos, extracted without TCA/acetone precipitation step, were separated using 2-DE for further analysis. The evaluation of the 2-DE were based on protein quality, streak free results and the number of spots in the 2-DE gels. The 2-DE separation was carried out in two phases, first based on protein charge $(\mathrm{pI})$ followed by molecular weight 
Table 1. A comparative protein yield analysis of Swietenia macrophylla embryos using different extraction protocols.

\begin{tabular}{lll}
\hline Protein extraction protocol & & Protein yield $(\mu \mathrm{g} / \mu \mathrm{L})$ \\
\hline Precipitation with TCA/acetone & Lysis buffer by Diane et al. (2004) & $3.0 \pm 1.16$ \\
& Lysis buffer by Tom et al. (2002) & $5.0 \pm 0.90$ \\
& Lysis buffer by Leonardo et al. (2010) & $5.0 \pm 1.21$ \\
\hline Without precipitation & Lysis buffer by Diane et al. (2004) & $12.4 \pm 0.95$ \\
& Lysis buffer by Tom et al. (2002) & $12.9 \pm 0.83$ \\
& Lysis buffer by Leonardo et al. (2010) & $5.2 \pm 0.14$ \\
\hline
\end{tabular}

(a)

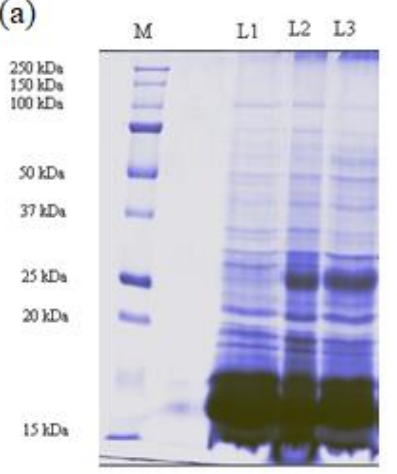

(c)

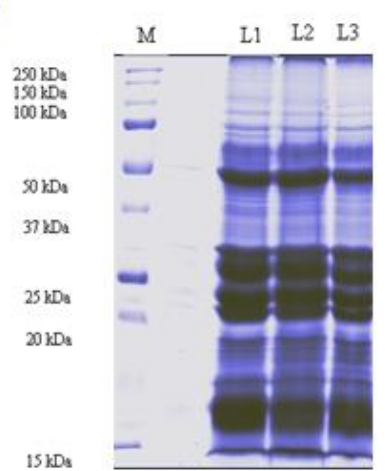

(b)

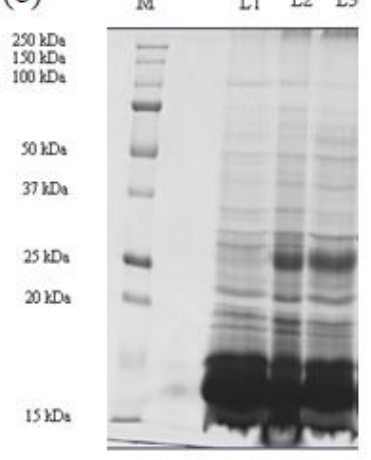

(d)

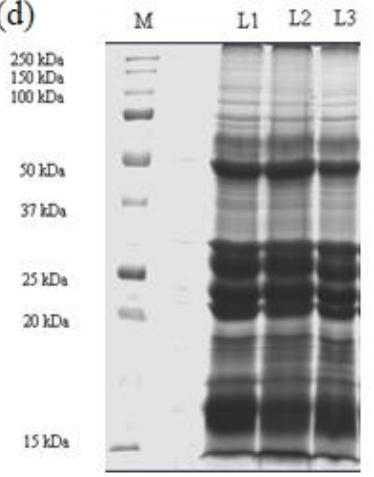

Fig 1. SDS-PAGE of S. macrophylla embryo proteins using different staining protocols (left - Coomassie brilliant blue; right - silver nitrate) obtained from with (a and b) and without (c and d) TCA/acetone precipitation step. M (marker); L1 (extraction using Diane et al., 2004); L2 (extraction using Tom et al., 2002); L3 (extraction using Leonardo et al., 2010).

Table 2. Total number of 2-DE protein spots from Swietenia macrophylla embryos using different extraction buffers. The gels were either stained with silver nitrate or Commassie brilliant blue.

\begin{tabular}{lcc}
\hline Extraction buffers (formulated by) & \multicolumn{2}{c}{ Resolved spots } \\
\cline { 2 - 3 } & Silver nitrate & Commassie brilliant blue \\
\hline L1 (Diane et al., 2004) & $191 \pm 25.5$ & $70 \pm 11.0$ \\
L2 (Tom et al., 2002) & $110 \pm 6.0$ & $55 \pm 3.0$ \\
L3 (Leonardo et al., 2010) & $240 \pm 3.5$ & $100 \pm 2.0$ \\
\hline
\end{tabular}


(a)

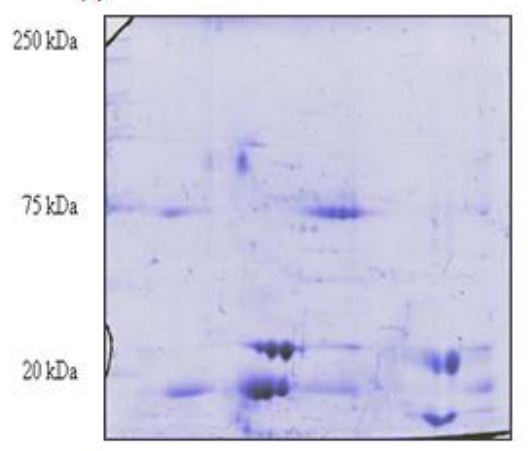

(c)

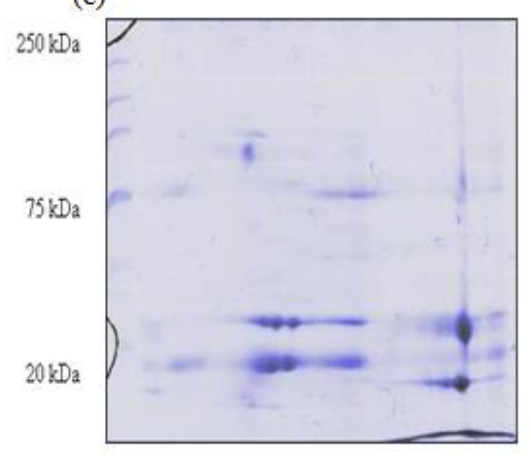

(e)

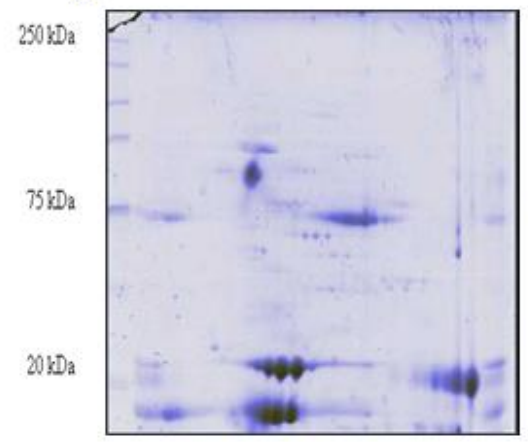

(b)

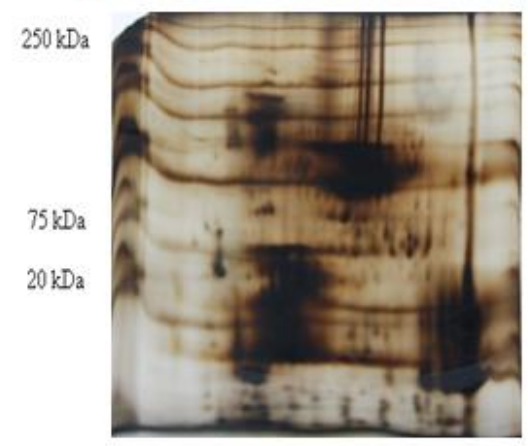

(d)

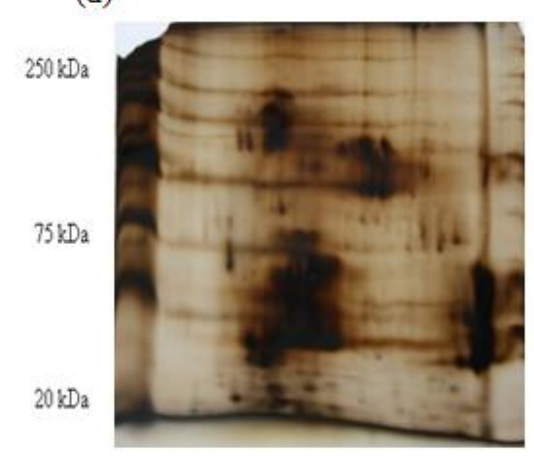

(f)

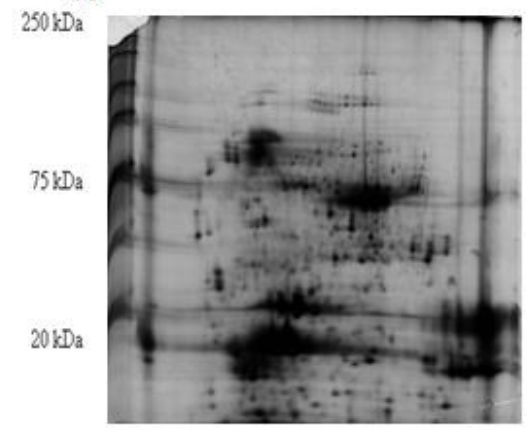

Fig 2. 2-DE of S. macrophylla embryo protein extracts by different lysis buffers formulated by Diane et al. (2004) (a and b), Tom et al. (2002) (c and d) and Leonardo et al. (2010) ( $d$ and e). The number of protein spots for each of the extraction methods is listed in Table 2.

Table 3. Recipes for the solutions used in the three different lysis buffers.

\begin{tabular}{llll}
\hline Chemical components & Diane et al. (2004) $-(\mathrm{L} 1)$ & Tom et al. (2002) - (L2) & Leonardo et al. (2010) - (L3) \\
\hline Chaotropes & $7 \mathrm{M}$ urea & $8 \mathrm{M}$ urea & 9 M urea \\
& $2 \mathrm{M}$ thiourea & & \\
Detergents & $4 \%$ CHAPS & $4 \%$ CHAPS & $4 \%$ CHAPS \\
& & & $0.5 \%$ triton X-100 \\
Reducing agent & $75 \mathrm{mM}$ DTT & $60 \mathrm{mM}$ DTT & $100 \mathrm{mM}$ DTT \\
Carrier & - & $2 \%$ pharmalyte $(\mathrm{pH} 3-10)$ & - \\
Others & $40 \mathrm{mM}$ Tris & - & - \\
\hline
\end{tabular}

(MW) separation. Plant tissues naturally contain secondary metabolites that act as barriers to the pathogen attack (Doughari, 2015). These substances interfere with the resolution of the resulting protein profiles on SDS-PAGE gel or 2-DE. For example, phenolic compounds can bind to proteins causing latitude lines and patches of shadows on the 2-DE gels (Vâlcu and Schlink, 2006). 


\section{Extraction buffers with different chemical constituents affect 2-DE resolution}

In this study, three different extraction buffers from Diane et al. (2004), Tom et al. (2002) and Leonardo et al. (2010) (L1, L2 and L3, respectively) were used to determine the best protein yield and 2-DE results. These buffers have been used to extract proteins from plant samples such as fruits and seeds (Diane et al., 2004; Tom et al., 2002; Leonardo et al., 2010). Hence, we could expect them to be also suitable for the extraction of our $S$. macrophylla seed samples. However, we observed some degree of differences between extractions using these different buffers.

Proteins extracted using the extraction buffer formulated by Diane et al. (2004) showed less efficient protein separation. Approximately, 191 \pm 25.5 spots detected using silver nitrate staining and at least $70 \pm 11.0$ spots detected using Coomassie brilliant blue (CBB) staining (Table 2). However, horizontal and vertical lines appeared on the gel and some of the large protein spots also were visible, indicating poor separation (Fig. 2 a and b). Protein profiles indicate that most proteins reside in the $\mathrm{pI}$ range of $\mathrm{pH} 4$ to 10 and a molecular weight range of 10 and $100 \mathrm{kDa}$. Meanwhile, the protein profiles obtained from the extraction buffer formulated by Tom et al. (2002) produced at least $110 \pm 6.0$ protein spots detected in silver stained gels, while for the CBB staining method approximately $55 \pm 3.0$ protein spots was detected (Table 2). This is less protein spots (Fig. $2 \mathrm{c}$ and d) compared to lysis buffer formulated by Diane et al. (2004) earlier.

Protein profiles obtained for the protein extraction buffer developed by Leonardo et al. (2010) showed the best resolution amongst the three protocols (Fig. 2 e and f). At least $240 \pm 3.5$ protein spots were detected using silver nitrate staining method, while $100 \pm 2.0$ protein spots were detected using $\mathrm{CBB}$ staining. The protein spots were in the range of $\mathrm{pH} 4$ to 9 with a molecular weight of between 10 and $150 \mathrm{kDa}$ (Fig. $2 \mathrm{e}$ and $\mathrm{f}$ ). The method used a combination of two detergents (4\% CHAPS and $0.5 \%$ triton X-100), one chaotropes (9 M urea) and one reducing agent (100 mM DTT) in the lysis buffer (Table 3). This buffer contained higher concentration of urea and DTT (9 M and $100 \mathrm{mM}$, respectively) compared to the other two buffers (7-8 M urea and 60-75 mM DTT) (Table 3). This may be beneficial for enhancing protein unfolding (Brian and Valerie, 2003) and stability (Hyun et al., 2012) contributed by these chemicals, respectively, which possibly leads to better protein spot visualization on the 2-DE gels (Fig. 2). The additional detergent $(0.5 \%$ triton $\mathrm{X}-100)$ in this lysis buffer which is not present in the other two buffers (Table 3) may also improve the protein solubility and isoelectric focusing step of the extracted protein. Detergents are mainly used to avoid protein loss due to aggregation and precipitation (Maserti et al., 2007) and evidently, the addition of another detergent. In this case $0.5 \%$ triton $\mathrm{X}-100$ ) has significantly improved the 2-DE resolution.

\section{Materials and Methods}

\section{Plant sample preparation}

Embryos from matured S. macrophylla seeds were used for this study. The seeds were collected from 17 years old trees. Seeds at physiological maturity, obtained from pre-dehiscent fruits, were collected in the area of Yan, Kedah, Malaysia. The embryos were pooled from 15-20 seeds and were ground in liquid nitrogen to a fine powder with a mortar and pestle. The samples were then stored in $-80^{\circ} \mathrm{C}$ until required.

\section{Protein extraction procedures}

Three different extraction methods, each using different lysis buffers were used to extract total proteins from $S$. macrophylla embryos. The finely powdered tissues were dissolved in either of the three buffers; L1 (7 M urea, $2 \mathrm{M}$ thiourea, $40 \mathrm{mM}$ tris, 75 $\mathrm{mM}$ dithiothreitol (DTT) and 4\% 3-[(3olamidopropyl)dimethylammonio]-1-propanesulfonate (CHAPS)), L2 (8 M urea, $60 \mathrm{mM}$ DTT, 4\% CHAPS and $2 \%$ pharmalyte $\mathrm{pH} 3-10$ ) or L3 (9 M urea, 4\% CHAPS, $0.5 \%$ triton $\mathrm{X}-100$ and $100 \mathrm{mM}$ DTT). The mixtures were incubated for $2 \mathrm{hr}$ at $4^{\circ} \mathrm{C}$. The extracts were then centrifuged at $6,000 \mathrm{x} \mathrm{g}$ for $20 \mathrm{~min}$. The supernatants were collected before the protein concentration was determined.

\section{Protein precipitation}

Another set of protein extraction protocol was done with TCA/acetone precipitation step prior to the protein solubilization using respective buffers (from L1, L2 and L3). The additional precipitation step was carried out at the beginning to possibly concentrate the proteins and to clean up the samples from any contaminants. The TCA/acetone precipitation protocol was carried out using $10 \%$ TCA in acetone. The extracts were precipitated for $45 \mathrm{~min}$ at $-20^{\circ} \mathrm{C}$ before centrifugation for $15 \mathrm{~min}$ at $12,000 \times \mathrm{g}$. The supernatants were discarded and the pellets were rinsed for two times using $0.07 \%$ 2-mercaptoethanol (2ME), 1 $\mathrm{mM}$ phenylmethanesulfonyl fluoride (PMSF) and 2 $\mathrm{mM}$ ethylenediaminetetra acetic acid (EDTA) in acetone then further centrifuged at $6,000 \mathrm{x} g$ for $15 \mathrm{~min}$ $\left(4^{\circ} \mathrm{C}\right)$. The protein pellets were dried and then dissolved separately using three different extraction buffers detailed as in the total protein extraction procedure above.

\section{Determination of protein concentration}

Protein concentration was quantified using 2-D Quant kit by GE Healthcare Biosciences Corp (USA) with bovine serum albumin (BSA) as a standard. Samples 
were stored at $-80^{\circ} \mathrm{C}$ until sodium dodecyl sulfate polyacrylamide gel electrophoresis (SDS-PAGE) and isoelectric focusing (IEF).

\section{SDS-PAGE}

Protein extracts were evaluated using SDS-PAGE. Proteins $(50 \mu \mathrm{g})$ were resuspended in $15 \mu \mathrm{L}$ of loading buffer. SDS-PAGE was performed in $12.5 \% \mathrm{w} / \mathrm{v}$ acrylamide gel using SDS electrophoresis buffer (25 $\mathrm{mM}$ Tris $\mathrm{pH} 8.3,192 \mathrm{mM}$ glycine and $0.1 \% \mathrm{w} / \mathrm{v}$ SDS) and a Mini-Protean II cell apparatus (Bio-Rad, USA) for two steps at $13 \mathrm{~mA} / \mathrm{gel}$ for $15 \mathrm{~min}$ and $18 \mathrm{~mA} / \mathrm{gel}$ untimed.

\section{$2 D$ gel electrophoresis (2-DE)}

Proteins were separated based on their pI using immobilized pH-gradient strips ( $\mathrm{pH} \mathrm{3-10} \mathrm{and} 7 \mathrm{~cm}$ ) and run using PROTEAN IEF CELL (Bio-Rad, USA). A total of $100 \mu \mathrm{g}$ of protein was used in the IEF in a total volume of $125 \mu \mathrm{L}$ rehydrating buffer consisting of $8 \mathrm{M}$ urea, 2\% CHAPS, $15 \mathrm{mM}$ DTT, $200 \mu \mathrm{L}$ bromophenol blue and $2 \%$ ampholytes of $\mathrm{pH} 3-10$. IPG strips were rehydrated at a passive mode for $12 \mathrm{hr}$ at $20^{\circ} \mathrm{C}$ using IEF cell. Subsequent IEF steps were then performed at $20^{\circ} \mathrm{C}$ using four different steps (step 1: $200 \mathrm{~V}$ for $200 \mathrm{~V} / \mathrm{h}$; step 2: $500 \mathrm{~V}$ for $500 \mathrm{~V} / \mathrm{h}$; step 3: $1000 \mathrm{~V}$ for $1000 \mathrm{~V} / \mathrm{h}$; step 4: $4000 \mathrm{~V}$ for $16000 \mathrm{~V} / \mathrm{h}$ ). After IEF, IPG strips were equilibrated using equilibration buffer containing $6 \mathrm{M}$ urea, $2 \% \mathrm{SDS}$, $20 \%$ glycerol and 2\% DTT. Then, the strips were immersed in the same equilibration buffer containing $2.5 \%$ iodoacetamide (IAA) instead of DTT. The strips were equilibrated for $15 \mathrm{~min}$ in each equilibration buffer at room temperature $\left(26^{\circ} \mathrm{C}\right)$. IPG strips was positioned on top of a vertical $12 \%$ polyacrylamide gel and electrophoresed at a constant current of $13 \mathrm{~mA}$ for $15 \mathrm{~min}, 16 \mathrm{~mA}$ for $20 \mathrm{~min}$ and finally $18 \mathrm{~mA}$ per gel.

\section{Protein visualization and image analysis}

Gels were stained with CBB G-250 (Neuhoff et al., 1998) and silver nitrate according to Chevallet et al. (2006). Stained gels were scanned using ImageScanner (GE Healthcare). Three biological replicates of each sample from different lysis buffers (without TCA/acetone precipitation) were run to examine the presence/absence of the protein spots. The IMAGE MASTER 2D PLATINUM software (GE Healthcare) was used to capture gel images for quantitative analysis of all the 2-DE according to the manufacturer's instructions. Vertical and horizontal streakings were also removed and background intensity was substracted during spot detection. The gels were then matched by landmarking common spots found in the different gels. Normalization was performed to correct variations in spot size and intensity between gels. Only consistent protein spots were considered for analysis.

\section{Conclusion}

We have developed a protein extraction protocol for $S$. macrophylla embryo. In this study, we compared the performance of three different lysis buffers for the extraction of proteins from $S$. macrophylla embryos, with or without TCA/acetone precipitation. The highest number of spots and the best resolution in 2-DE map was developed using protocol without TCA/acetone and lysis buffer from Leonardo et al. (2010). This suggests that using higher concentration of chaotropes (urea) and reducing agents (DTT) and two detergents (CHAPS and triton X-100) as in the lysis buffer formulated by Leonardo et al. (2010) contributed to the higher number of spots detected. This is the very first report which evaluated different methods for the analysis of $S$. macrophylla proteins from embryo. Results from this study can provide a basic 2-DE reference map of $S$. macrophylla embryos which can be used to investigate the molecular mechanism of this economically important tree species.

\section{Acknowledgement}

This work was carried out with financial support from the government of Malaysia under " $10^{\text {th }}$ Malaysia Plan". The authors are thankful to Seed Technology Laboratory headed by Madam Nashatul Zaimah Noor Azman for assistance on $S$. macrophylla seed procurement and testing.

\section{References}

Amme S, Matros A, Schlesier B, Mock HP (2006) Proteome analysis of cold stress response in Arabidopsis thaliana using DIGE-technology. J Exp Bot. 57(7):1537-1546.

Brian JB, Valerie D (2003) The molecular basis for the chemical denaturation of proteins by urea. Proc Natl Acad Sci USA. 100(9):5142-5147.

Carpentier SC, Witters E, Laukens K, Deckers P (2005) Preparation of protein extracts from recalcitrant plant tissues: an evaluation of different methods for two-dimensional gel electrophoresis analysis. Proteomics. 5:2497-2507.

Canovas FM, Dumas-Gaudot E, Recorbet G, Jorrin J, Mock HP, Rossignol M (2004) Plant proteome analysis. Proteomics. 4:285-298.

Chevallet M, Luche S, Rabilloud T (2006) Silver staining of proteins in polyacrylamide gels. Nat Protoc. 1(4):1852-1858.

CITES (2002) Appendix II implementation for bigleafed mahogany Swietenia macrophylla. TRAFFIC International.

Diane B, David O, William L, Tanya C (2004) A general method for two-dimensional protein electrophoresis of fruit samples. Postharvest Biol Tec. 32:175-181.

Doughari JH (2015) An overview of plant immunity. J Plant Pathol Microbiol. 6:322. 
Ellis RH, Hong TD, Roberts EH (1992) The lowmoisture content limit to the negative logarithmic relation between seed longevity and moisture content in three subspecies of rice. Ann Bot. 69:53-58.

El-Maarouf-Bouteau H, Bailly C (2008) Oxidative signaling in seed germination and dormancy. Plant Signal Behav. 3(3):175-182.

Gorg A, Weiss W, Dunn MJ (2004) Current twodimensional electrophoresis technology for proteomics. Proteomics. 4:3665-3685.

Hyun L, Jaime T, Lena T, Rima C, Anuradha M, Michael E (2012) Reducing agents affect inhibitory activities of compounds: results from multiple drug targets. Anal Biochem. 423(1):46-53.

Krisnawati H, Kallio M, Kanninen M (2011) Swietenia macrophylla King: ecology, silviculture and productivity. Center for International Forestry Research (CIFOR), Bogor, Indonesia.

Leonardo LCD, Tiago SB, Vanildo S, Claudete SC, Andrej S, Eny ISF (2010) Two-dimensional gel electrophoretic protein profile analysis during seed development of Ocotea catharinensis: a recalcitrant seed species. Braz J Plant Physiol. 22(1):23-33.

Maldonado AM, Echevarria-Zomeno S, Jean-Baptiste S, Hernandez M, Jorrin-Novo JV (2008) Evaluation of three different protocols of protein extraction for Arabidopsis thaliana leaf proteome analysis by twodimensional electrophoresis. Proteomics. 71:461472.

Maserti BE, Della CCM, Luro F, Morillon R, Cini M, Caltavuturo L (2007) A general method for the extraction of citrus leaf proteins and separation by 2D electrophoresis: a follow up. J Chromatogr B. 849:351-356.

Nandakumar MP, Shen J, Raman B, Marten MR (2003) Solubilization of TCA precipitated microbial proteins via $\mathrm{NaOH}$ for two dimensional electrophoresis. J Proteome Res. 2:89-93.

Neuhoff V, Arold N, Taube D, Ehrhardt W (1988) Improved staining of proteins in polyacrylamide gels including isoelectric focusing gels with clear background at nanogram sensitivity using coomassie brilliant blue G-250 and R-250. Electrophoresis. 9:255-262.

Saravanan RS, Rose JK (2004) A critical evaluation of sample extraction techniques for enhanced proteomic analysis of recalcitrant plant tissues. Proteomics. 4(9):2522-2532.

Shaw MM, Riederer BM (2003) Sample preparation for two dimensional gel electrophoresis. Proteomics. 3(8):1408-1417.

Tom B, Stenstedt T (2002). 2-D electrophoresis: principles and methods. Sweden: Amersham Bioscience.

Wang W, Vignani R, Scali M, Cresti M (2006) A universal and rapid protocol for protein extraction from recalcitrant plant tissues for proteomic analysis. Electrophoresis. 27(13):2782-2786.

Wang W, Vignani R, Scali M, Sensi E, Tiberi P, Cresti M (2004) Removal of lipid contaminants by organic solvents from oilseed protein extract prior to electrophoresis. Anal Biochem. 329(1):41-139.

Vâlcu CM, Schlink K (2006) Reduction of proteins during sample preparation and two-dimensional gel electrophoresis of woody plant samples. Proteomics 6(5):605-1599.

Valente KN, Choe L, Lenhoff A, Lee K (2012) Optimization of protein sample preparation for twodimensional electrophoresis. Electrophoresis. 33:1947-1957. 